\title{
Potentials of Pleurotus ostreatus and Aspergillus sp. in the Bio-removal of Heavy Metals from a Tropical Soil Receiving Illegal Crude Oil Refinery Products
}

\section{Sampson T*, Ugboma CJ and Mbonu NE}

Department of Microbiology, Rivers State University, Port Harcourt, Rivers State, Nigeria

*Corresponding Author: Sampson T, Department of Microbiology, Rivers State University, Port Harcourt, Rivers State, Nigeria.
Received: April 06, 2021

Published: April 27, 2021

(C) All rights are reserved by Sampson T., et al.

\begin{abstract}
Unauthorized refining of crude oil has in recent time posed significant human and environmental health risk. This study was therefore aimed at evaluating the efficacy of Pleurotus ostreatus and Aspergillus sp. in the bioremoval of heavy metals from soil impacted with products from illegal refineries. The experimental setup of the 42-day study involved recreating the samples collected from contaminated and uncontaminated (control) tropical soil in three (3) vessels and labeled as Flask A (containing 300g of uncontaminated (control) original sample to monitor the natural process; Flask B (containing 300g of sterilized sample (Negative control); Flask C (containing 300g of the sample seeded with the spawn and Aspergillus sp). The concentrations of heavy metals were determined using an atomic absorption spectrophotometer. Soil baseline physicochemical composition was determined to have $\mathrm{pH}$ as 6.18, Temperature of 29.2oC, Total Organic Carbon of $7.58 \mathrm{mg} / \mathrm{kg}$ and Phosphate concentration of $37.56 \mathrm{mg} / \mathrm{kg}$. The result from the studied revealed that experimental setup C, containing fungal inoculum had the best removal rates for mercury, arsenic and lead, with the concentrations declining from $1.05264 \mathrm{mg} / \mathrm{kg}$ to 0.00628 for Mercury (Hg); Arsenic (As), $78069 \mathrm{mg} /$ $\mathrm{kg}$ to $0.18912 \mathrm{mg} / \mathrm{kg}$; lead $(\mathrm{Pb}) 13.47452 \mathrm{mg} / \mathrm{kg}$ to $4.03056 \mathrm{mg} / \mathrm{kg}$, representing a 99.3\%, 91\%, and 67.7\% removal of $\mathrm{Hg}$, As and $\mathrm{Pb}$, respectively. Statistical analysis revealed a strong correlation $(\mathrm{p}<0.05)$ between the heavy metal removal and change in fungal biomass. This study has demonstrated the role of fungi in the removal of heavy metals from the contaminated media. This potential should therefore be harnessed as a road map for eco-recovery.
\end{abstract}

Keywords: Aspergillus sp; Bio-removal; Heavy Metals; Illegal Refinery; Tropical Soil; Pleurotus ostreatus

\section{Introduction}

The waste resulting from illegal crude oil refining are usually discharged untreated into the environment (terrestrial and aquatic environs). The discharged waste contains diverse heavy metals that contaminate the environment, thereby causing environmental pollution which could affect both plants and animals. Siddiquee., et al. (2015) [1] opined that wastes containing metals are either directly or indirectly discharged into the environment and these wastes are responsible for the serious environmental pollution which has become a major threat toward human and plants especially when they are assimilated in large quantity. Heavy metals "can bind to vital cellular components, such as structural proteins, enzymes, and nucleic acids, and interfere with their functioning and long-term exposure could lead to cancer, central and peripheral nervous system impairment, including circulatory effects [2].

Bioremoval of heavy metals involves the use of biological processes or living organisms such as bacteria, fungi, plant, etc. to completely remove or reduce the concentration of heavy metals in the environment. The use of fungi in bioremediation is well documented. The use of fungi as bioremoval agent is known as mycoremediation. Mycoremediation is a form of bioremediation in which fungibased technology is used to decontaminate the environment. Fungi have been proven to be a very cheap, effective and environmentally sound way for helping to remove a wide array of toxins from dam- 
aged environments or wastewater [3]. Recent studies have shown that $P$. ostreatus a fungus could degrade a variety of polycyclic aromatic hydrocarbons (PAH). It also has the ability to degrade $\mathrm{PAH}$ in non-sterile soil both in the presence and in the absence of cadmium and mercury [4]. Arica., et al. (2003) [5], reported the use of turkey tail mushroom and phoenix oyster mushroom mycelia to eliminate $97 \%$ mercury ion from water. As observed by Humer., et al. (2004) [6], mushroom degraded copper and chromium in treated woods. Members of the genus Aspergillus are known for their versatility to degrade a diversity of toxic compounds ranging from heavy metals, textile dyes, aromatic compounds, pesticides etc. A. flavus and A. niger have been reported for their capacity to reduce heavy metals such as $\mathrm{Cr} 6+$ to $\mathrm{Cr} 3+$ [7]. Another species, $A$. foetidus isolated from a wastewater treatment plant was found to be tolerant to high concentrations of lead (Pb) up to $200 \mathrm{mg} / \mathrm{L}$ which was removed through biosorption [8] as was also observed in bioremediation of aqueous substrates containing mercury (II) by A. flavus strain which was able to remove about 98\% mercury in presence of $10 \mathrm{mg} / \mathrm{L}$ mercury in the medium [9]. Mumtaz., et al. (2013) [10] demonstrated the potential of fungi like Aspergillus, Cryptococcus, Penicillium and Curvularia for bioremediation of uranium contaminated soils which was attributed to their uranium binding ability. Bioremediation of heavy metals from artisanal crude oil refinery (kpo-fire) impacted soil using bacterial species such as Bacillus flexus and Pseudomonas aeruginosa has been earlier published [11]. There is however a growing interest in understanding the role of fungal species in remediating environments inundated with heavy metals, thus bringing such environments to their pristine state. This instant research was therefore, carried out to determine the effectiveness of using fungal isolates such as Pleurotus ostreatus and Aspergillus species in the removal of heavy metals resulting from illegal ("kpo-fire") residues.

\section{Materials and Methods}

Sample collection

Soil samples contaminated with "Kpo-fire" residue was collected in clean sterile container from a site in Ngie community, Degema Local Government Area of Rivers State, Nigeria. The depth of soil sample collected was $0-10 \mathrm{~cm}$. The sample was taken to the laboratory immediately after collection for immediate analysis.

\section{Study duration}

The study duration was for six months. The study was carried out between the month of March and September 2019. The experimental set up was monitored for 42 days after isolation, purification and identification of the isolates.
Physico-chemical and heavy metal analysis of the crude oil impacted soil

Prior to the experimental setup, the physicochemical parameters such as temperature, $\mathrm{pH}$, biological oxygen demand (BOD), total organic carbon (TOC), phosphate concentration and nitrate concentration were studied using standard procedures as previously described [12]. The heavy metals such as Boron, Cadmium, Arsenic and Mercury were determined using an Atomic Absorption Spectrophotometer.

\section{Isolation of fungal isolates}

The heterotrophic fungi were enumerated and isolated using Sabouraud dextrose agar (SDA) supplemented with antibiotic as described by earlier researchers [13]. In this current study, tetracycline antibiotic was used. The addition of tetracycline antibiotic was to suppress the proliferation of bacteria. An aliquot $(0.1 \mathrm{ml})$ of the decimal dilutions of the sample was cultured in triplicates on freshly prepared SDA plates supplemented with tetracycline antibiotics. The cultured plates were incubated for 5 - 7 days at $25^{\circ} \mathrm{C}$. Distinct fungal isolates were isolated by growing respective spores in fresh SDA plates. This was done repeatedly until pure fungi cultures emerged. Identification of fungal isolates was done as described by previous studies [14,15]. Fungi morphology and microscopic appearance was compared with those enlisted in the book of fungi [16].

\section{Preparation of fungal inoculum}

The fungal inoculum was prepared as described by [17]. In this method, pure cultures of Pleurotus ostreatus and Aspergillus sp was suspended in SDA broth and incubated at $25^{\circ} \mathrm{C}$ for 48 hours. After which, $5 \mathrm{ml}$ each of the Pleurotus ostreatus and A. niger which has been adjusted to $1.5 \times 10^{8}$ cells were transferred into the experimental set up as shown below.

\section{Bioremediation setup}

Three different treatment options were set up and labeled A-C in a sterile conical flask:

- Flask A: Contained $300 \mathrm{~g}$ of the original sample to monitor the natural process (Control).

- $\quad$ Flask B: Contained 300g of sterilized sample (negative control)

- $\quad$ Flask D: Contained 300g of the sample seeded with the consortium of Pleurotus ostreatus and Aspergillus sp. 


\section{Results}

The result of the physicochemical parameters and heavy metal analysis of the kpo-fire soil sample is presented in table 1 . The $\mathrm{pH}$, temperature, electrical conductivity and lead of the kpo-fire soil sample values were 6.9, 24.91, 980.74 and 13.47452 , respectively. These values are within the DPR target values. The Arsenic and Mercury concentration of the kpo-fire soil sample which were 2.78 and $1.05 \mathrm{mg} / \mathrm{kg}$ were above the DPR target values.

\begin{tabular}{|c|c|c|}
\hline Parameters & $\begin{array}{c}\text { Kpo-fire } \\
\text { soil sample }\end{array}$ & $\begin{array}{c}\text { Target values } \\
\text { (DPR, 2002) }\end{array}$ \\
\hline $\mathrm{pH}$ & 6.9 & $6.5-8.5$ \\
\hline Temperature $\left({ }^{\circ} \mathrm{C}\right)$ & 24.91 & 30 \\
\hline Electrical conductivity $(\mu \mathrm{S} / \mathrm{cm})$ & 980.74 & 4000 \\
\hline Arsenic $(\mathrm{mg} / \mathrm{kg})$ & 2.78 & 1.0 \\
\hline Mercury $(\mathrm{mg} / \mathrm{kg})$ & 1.05 & 0.30 \\
\hline Lead $(\mathrm{mg} / \mathrm{kg})$ & 13.47452 & 85 \\
\hline
\end{tabular}

Table 1: Physicochemical parameter and heavy metal composition of the "Kpo-fire" soil ample.

Keys: DPR: Department of Petroleum Resources.

The fungal population during the bioremoval study of heavy metals varied across the period of the study (Figure 1). The fungal population of the set-up A which was $3.9 \log _{10} \mathrm{CFU} / \mathrm{ml}$ declined in day 21 but increased in the 42 . Also, the set-up D which had initial population of $6.1 \log _{10} \mathrm{CFU} / \mathrm{g}$ and increased in Day 21 and Day 42 .

Flask A 300g of the original sample to monitor the natural process (Control): Flask B 300g of sterilized sample (negative control), Flask. Flask D 300g of the sample seeded with the spawn and Aspergillus sp.

The result for the bioremoval of Lead from the kpo-fire soil is illustrated in figure 2 . The result showed a great decline in the Lead content of the soil as a result of the activities of pleurotus and $\mathrm{As}$ pergillus sp. The initial Lead content which was $12.48 \mathrm{mg} / \mathrm{kg}$ was significantly reduced to $9.15 \mathrm{mg} / \mathrm{kg}$ and $4.03 \mathrm{mg} / \mathrm{kg}$ in Days 21 and 42 , respectively. The natural process (set-up A) despite having a remediation potential, the amount of Lead removed was very minute for the whole period of study compared to the set-up D.

Similarly, the bioremoval potential of Pleurotus and Aspergillus on Arsenic and Mercury compound as represented in figure 3 and 4 , respectively showed significant decline on the heavy metals from the Day 0 to Day 42.

\section{Discussion}

Results from the study showed that the pH of the "kpo-fire" impacted soil was slightly acidic. The $\mathrm{pH}$ of near alkalinity of soil samples collected from places where artisan refining of crude oil is carried out has been reported [18]. The values of $\mathrm{pH}$, temperature and electrical conductivity of the soil in this current study agree very strongly with the report of [19]. These parameters are crucial in the monitoring of the environmental quality of a media especially in the interaction of exchangeable cations, the temperature factor indicates the solubility of nutrients and formation of metaloxide complexes [20]. Furthermore, Chima and Vure (2014) [21] suggested that the $\mathrm{pH}$ and temperature indices of the soil were also related to the geochemical indices such as the soil pore-sizes, airquality and permeability [22].

The increased population of fungi from day 0, day 21 and day 42 of the treated set-up during the bioremediation process could be evidence that the heavy metals in the kpo-fire soil served as nutrient which aided in the fungi load. The fungal load in the controlled sample which was not treated with fungi consortium showed slight growth across the period of study. Thus, there could be metabolic activities taking place which had also caused an increased fungi population. This statement agreed with [23] who suggested that the conversion of spent metabolites and intermediates by fungi flora could cause an increase in fungi population. Despite the variation in the fungal load across the period of remediation, the fungal load showed no significant $(\mathrm{p}>0.05)$ difference. In this current study, the heavy metals present in the soil were seen to decline from the initial concentration. Stanley., et al. (2018) [24] in a study opined that there was an increase in fungal biomass during the bioremediation of total petroleum hydrocarbon (TPH) of a polluted site. Thus, this agreed with findings in this current study which showed a continual increase in fungi load across the period of remediation. Bioremediation using spawn of Pleurotus sp and agro-residues has shown great potential as documented by an earlier researcher [25]. The results of this current study suggest that Pleurotus sp and $A s$ pergillus niger could be used in the biodegradation or remediation of "kpo-fire" contaminated soil. Microorganisms have the potential to convert harmful substances into simpler or into limits that are acceptable via a chain of reaction or succession. This statement is in agreement with the work of Sampson., et al. (2016a) [17] who reported that microbes converting harmful pollutants into less harmful ones follow a predictable and model-feasible bioprocess. 


\section{Conclusion}

The bioremoval or bioremediation potential of Pleurotus ostreatus and Aspergillus niger on soil samples contaminated with residues from artisan refining of crude oil (Kpo-fire) showed useful potentials, and are highly recommended for bioremediation of heavy metal.

The study has clearly shown that the organisms in consortium were able to reduce heavy metals such as lead, arsenic and mercury to minute values within 42 days.

\section{Bibliography}

1. Siddiquee S., et al. "Heavy Metal Contaminants Removal from Wastewater Using the Potential Filamentous Fungi Biomass: A Review". Journal of Microbial and Biochemical Technology 7 (2015): 384-393.

2. Harvey P J., et al. "Identification of the sources of metal (lead) contamination in drinking waters in north-eastern Tasmania using lead isotopic compositions". Environmental Science and Pollution Research 22.16 (2015): 12276-12288.

3. Deshmukh R., et al. "Diverse Metabolic Capacities of Fungi for Bioremediation”. Indian Journal of Microbiology 56.3 (2016): 247-264.

4. Adenipekun $\mathrm{C} \mathrm{O}$ and Lawal R. "Uses of mushrooms in bioremediation: A review". Biotechnology and Molecular Biology Reviews 7.3 (2012): 62-68.

5. Arica M Y., et al. "Comparative biosorption of mercuricion from aquatic systems by immobilized live and heat inactivated Trametes versicolor and Pleurotus sajo-caju". Bioresource Technology 89.2 (2003): 145-154.

6. Humer M., et al. "Fungal bioremediation of copper, chromium and boron treated wood as studied by electron pragmatic resonance". International Biodeterioration and Biodegradation 53 (2004): 25-32.

7. Bennett R M., et al. "Reduction of hexavalent chromium using fungi and bacteria isolated from contaminated soil and water samples". Chemistry and Ecology 29 (2013): 320-328.

8. Chakraborty S., et al. "Biochemical characterization of a leadtolerant strain of Aspergillus foetidus: an implication of bioremediation of lead from liquid media". International Biodeterioration and Biodegradation 84 (2013): 134-142.
9. Kurniati E., et al. "Potential bioremediation of mercury-contaminated substrate using filamentous fungi isolated from forest soil”. Journal of Environmental Science 26 (2014): 12231231.

10. Mumtaz S., et al. "Fungi outcompete bacteria under increased uranium concentration in culture media". Journal of Environmental Radioactivity 120 (2013): 39-44.

11. Ugboma CJ., et al. "Bioremediation of Heavy Metals from Artisanal Crude Oil Refinery (Kpo-Fire) Impacted Soil using Bacillus flexus and Pseudomonas aeruginosa in Ngie Community, Degema Local Government Area, Rivers State, Nigeria”. Journal of Applied Sciences and Environmental Management 24.12 (2020): 2049-2054.

12. Tochukwu E E., et al. "Physico-Chemical Analysis of Soils Proximate to Artisanal Refining Plants in Southern Nigeria". British Journal of Environmental Sciences 5.1 (2017): 18-26.

13. Douglas S I and Kpormon L B. "Comparative Ecotoxicological Assay of E-waste (phone batteries) on some Aquatic Micro Flora". Journal of Advances in Biology and Biotechnology 17.2 (2018): 1-10.

14. Douglas S I and Robinson V K. "Fungal Pollution of Indoor Air of Some Health Facilities in Rivers State". International Journal of Tropical Disease and Health 32.2 (2018): 1-7.

15. Douglas S I and Robinson V K. "Indoor Microbiological Air Quality in Some Wards of a Tertiary Health Institution in Port Harcourt, Nigeria". Journal of Pharmacy and Biological Sciences 14 (2019): 44-50.

16. Sarah K., et al. "Descriptions of medical fungi" (3rd edn) (2016).

17. Sampson T., et al. "Simulating biodegradation of hydrocarbon pollutants under slow nutrient delivery conditions". Microbiology Research Journal International 14.5 (2016a): 1-8.

18. Sampson T., et al. "Production and application of agar based slow-release fertilizers, in the bioremediation of petroleum hydrocarbon-impacted soil". British Biotechnology Journal 13.4 (2016b): 1-13.

19. Eze C., et al. "Chromium (III) and its effects on soil microbial activities and phytoremediation potentials of Arachis hypogea and Vigna unguiculata". African Journal Biotechnology 17 (2018): 1207-1214. 
20. Orhorhoro E., et al. "Laboratory-scale bioremediation of crude oil polluted soil using a consortia of rhizobacteria obtained from plants in Gokana-Ogoni, Rivers State". Journal of Advance Microbiology 9 (2018): 1-17.

21. Chima U D., et al. "Implications of crude oil pollution on natural regeneration of plant species in an oil-producing community in the Niger Delta Region of Nigeria". Journal of Forestry Research 25.4 (2014): 915-921.

22. Effiong E., et al. "Niche-proxies of Hydrocarbon-impacted Rhizosphere Soil of Weeds of Bodo in Gokana, Rivers State, Nigeria". Archives of Current Research International (2019): 1-14.

23. Odokuma L O. "The genius in the microbe: an indispensable tool for the management of xenobiotic mediated environmental flux". Inaugural Lecture Series 87 (2012).

24. Stanley H O., et al. "Crude Oil Degradation Using Spent Mushroom Compost (SMC) of Pleurotus florida". Asian Journal of Advanced Research and Report (2018): 1-7.

25. Stanley H O., et al. "Bioremoval of heavy metals from effluent of Port Harcourt Refinery using Pluerotus ostreatus". Journal of Petroleum and Environmental Biotechnology 7 (2017): 324.

\section{Assets from publication with us}

- Prompt Acknowledgement after receiving the article

- Thorough Double blinded peer review

- Rapid Publication

- Issue of Publication Certificate

- High visibility of your Published work

Website: https://www.actascientific.com/

Submit Article: https://www.actascientific.com/submission.php Email us: editor@actascientific.com

Contact us: +919182824667 